\title{
Susceptibility of Culex quinquefasciatus (Diptera: Culicidae) to malathion in Sargodha district, Pakistan
}

\author{
Hafiz Muhammad Tahir ${ }^{{ }^{*}}$, Kishwar Hussain ${ }^{1}$, Azhar Abbas Khan $^{2}$, Sajida Naseem ${ }^{1}$, \\ Hamza Tanveer Malik ${ }^{3}$, Abida Butt ${ }^{4}$, Rabia Yaqoob ${ }^{1}$ \\ ${ }^{1}$ Department of Biological Sciences, University of Sargodha, Sargodha, Pakistan; "Corresponding Author: hafiztahirpk1@yahoo.com \\ ${ }^{2}$ Department of Agricultural Entomology, University College of Agriculture, University of Sargodha, Sargodha, Pakistan \\ ${ }^{3}$ College of Medicine, American University of Antigua, New York, USA \\ ${ }^{4}$ Department of Zoology, University of Punjab, Lahore, Pakistan
}

Received 18 August 2013; revised 21 September 2013; accepted 6 October 2013

Copyright (C) 2013 Hafiz Muhammad Tahir et al. This is an open access article distributed under the Creative Commons Attribution License, which permits unrestricted use, distribution, and reproduction in any medium, provided the original work is properly cited.

\begin{abstract}
The present study was designed to evaluate the susceptibility of Culex quinquefasciatuns against malathion in Sargodha district of Pakistan. The activities of detoxifying enzymes i.e., $\beta$-esterases, GSTs and monooxygenases were also estimated. Our results revealed 100 percent mortality in insecticide treated groups after 24 hours of exposure. There was no difference in the activities of insecticide detoxifying enzymes between control and treated groups. We concluded from our work that malathion is still effective against C. quinquefasciatuns in the area for control of mosquito population.
\end{abstract}

Keywords: C. quinquefasciatuns; Susceptibility; Esterases; Glutathione S-Transfereases; Malathion

\section{INTRODUCTION}

Mosquitoes are vector agents that cause diseases by transmitting the virus and parasite from one person to another. Mosquito-borne diseases are responsible for significant global morbidity and mortality, and are disproportionately affecting children and adolescents [1]. Culex mosquitoes, especially C. quinquefasciatus, are the chief vectors of Wuchereria bancrofti that cause a disease known as bancroftian filariasis. This disease is common in many regions of the world including the Middle East and Eastern Mediterranean countries [2]. C. quinquefasciatus may also cause protozoan, viral, parasitic and helminthic diseases.

Insecticides are considered as the most important components in the global mosquito control efforts [3], but due to their injudicious use, Culex mosquitoes have developed resistance against them [4]. More than 100 mosquito species are known to have developed resistance to one or more insecticides. Resistance to pyrethroids and organophosphates has been found in C. quinquefasciatus $[5,6]$.

The insecticide detoxifying enzymes have been described to confer insecticide resistance in mosquitoes which are esterases, cytochrome P-450-dependent monooxygenases and glutathione $S$-transferases [7]. Esterases are mostly involved in detoxification of organophosphates and carbamates [8]. Glutathione S-transferases are important family of multifunctional enzymes [9]. The monooxygenases P450 are phase-I metabolic enzymes [10] and are considered as the only enzymes to oxidize insecticides in insects.

For the successful implementation of mosquito control in a specific area, it is necessary to assess their resistance status in that area. The aim of present study was to conduct the susceptibility tests of $C$. quinquefasciatus against malathion, so the resistance status of $C$. quinquefasciatus in the study area may be determined. Activity of insecticide detoxifying enzymes was also determined in insecticide treated and control group.

\section{MATERIALS AND METHODS}

Samples were collected from University of Sargodha, Punjab, Pakistan by using aspirator. Only blood fed female mosquitoes were used for study. Bioassays were performed to determine susceptibility of $C$. quinquefasciatus against malathion. Three concentrations of malathion insecticide [i.e., recommended field dose (1.5 $\mu 1 / 500 \mathrm{ml}), 3 / 4 \mathrm{th}$ of recommended field dose (1.12 $\mu 1 / 500 \mathrm{ml})$ and $1 / 2$ of recommended field dose $(0.75$ $\mu 1 / 500 \mathrm{ml}$ ) were used]. For residual bioassay specimens were divided into control and treated groups $(\mathrm{n}=30$ in 
each group). Treated group was exposed to insecticide impregnated filter paper, for one hour and then transferred to clean holding jar. Control group was exposed to water impregnated filter paper. Mortality was observed at discrete intervals for 24 hours. The bioassay tests were repeated thrice.

In order to evaluate the role of esterases, glutathioneS-ransferases and Monooxygenases in insecticide resistance, mosquitoes were exposed to sub-lethal dose of malathion for one hour and then shifted to clean jars. After 24 hours of exposure, survivors were frozen at $-20^{\circ} \mathrm{C}$ for $15-20$ minutes in order to immobilize them, and then their wings, legs and abdomen were removed. Rest of the body was homogenized in $400 \mu 1$ of chilled phosphate buffer $(0.1 \mathrm{M}, \mathrm{pH} 7.0)$ containing $0.01 \%(\mathrm{w} / \mathrm{v})$ of triton X-100. The crude homogenate was centrifuged at $13,000 \mathrm{rpm}$ for 5 minutes. The supernatant was collected and used further as enzyme source for biochemical estimation of non-specific esterase ( $\beta$-esterases), glutathione-S-transferases (GST) and monooxygenases.

To measure the activity of non-specific esterases method described by Baker et al. [11] was followed. Bnaphthyl acetate (Substrate B) was used as substrate. The activity of Glutathione-S-transferases towards 1-chloro-2, 4-dinitrobenzene (CDNB) was estimated according to methods elaborated by Habig et al. [12]. The activity of monooxygenases was determined by the method described by Vulule et al. [13]. To compare the activity of enzymes between control and insecticide treated group two sample t-tests was applied using Minitab 13.2.

\section{RESULTS}

C. quinquefasciatus population was found susceptible to the all tested concentartions of malathion. After 24 hours of exposure 100 percent mortality of mosquitoes (all mosquitoes in a group died treated with each dose) was observed at each concentration. However, no mortality was recorded in control group (Table 1).

When the activity of Esterases between control and treated groups were compared, non-significance difference was observed $(\mathrm{df}=11 ; \mathrm{T}$-value $=-0.74 ; \mathrm{P}$-value $=$ 0.474 , Figure 1). Although the activities of Glutathione-

Table 1. Mortality in C. quinquefasciatus against different concentrations of malathion.

\begin{tabular}{cccccc}
\hline $\begin{array}{c}\text { Concentraions } \\
(\mu \mathrm{l} / 500 \mathrm{ml}) \text { of } \\
\text { malathion }\end{array}$ & $\begin{array}{r}\text { Number of musquitoes died at different time intervals } \\
\text { Total moqquitoes in each group were }\end{array}$ \\
\cline { 2 - 6 } & $4 \mathrm{hrs}$ & $8 \mathrm{hrs}$ & $12 \mathrm{hrs}$ & $16 \mathrm{hrs}$ & $24 \mathrm{hrs}$ \\
\hline 0.00 (Control) & 0 & 0 & 0 & 0 & 0 \\
0.75 & 20 & 23 & 24 & 26 & 30 \\
1.12 & 25 & 25 & 25 & 25 & 30 \\
1.5 & 25 & 28 & 28 & 28 & 30 \\
\hline
\end{tabular}

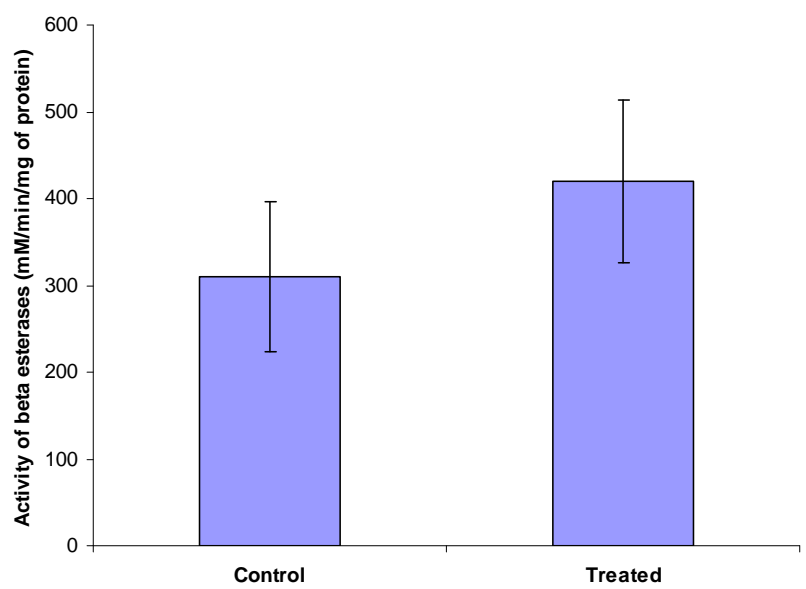

(a)

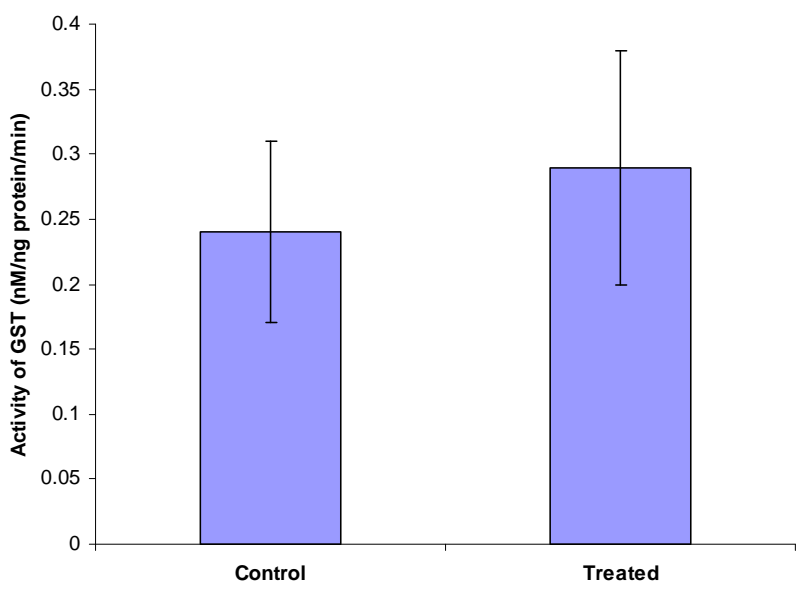

(b)

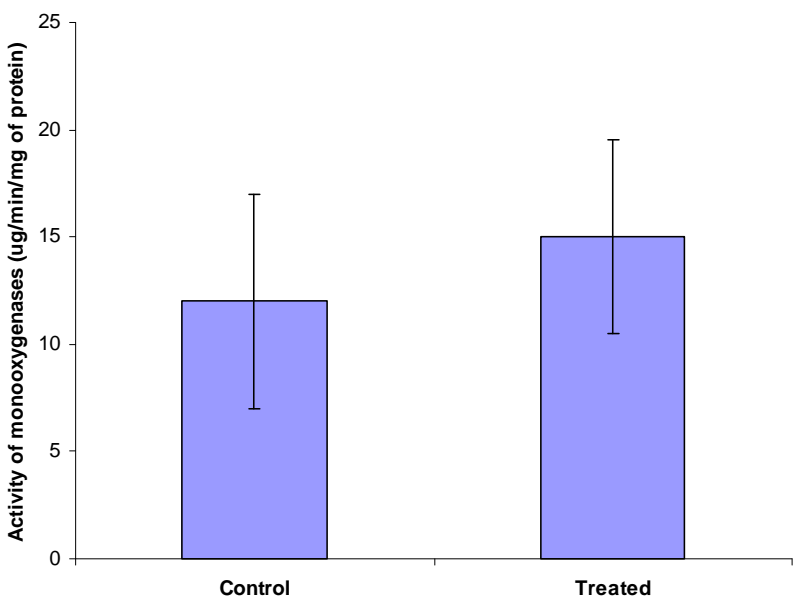

(c)

Figure 1. Activities of esterases (a) Glutathione-s-transferases (b) and Monooxygenases (c) in control and treated group.

s-transferases and Monooxygenases in the treated group were higher but statistically difference was non-significant $(\mathrm{df}=18 ; \mathrm{T}$-value $=-0.40 ; \mathrm{P}$-value $=0.697$ for Glutathione-s-transferases and $\mathrm{df}=11 ; \mathrm{T}$-value $=-1.711$; $\mathrm{P}$-value $=0.148$ for Monooxygenases) as depicted in 
Figure 1.

\section{DISCUSSION}

Mosquitoes are the major public health pests and are vectors for many diseases, such as malaria and West Nile Virus [14]. Various methods are being used by researchers to control the mosquitoes. Insecticides are frequently used to control the mosquitoes, but over time these can build up a resistance to insecticides [8].

Results of present study showed malathion to be the potent insecticide to produce a high level of mortality in C. quinquefasciatus. Duran and Stevenson [15] also reported malathion susceptibility in C. quinquefasciatus. However, these results are contrary to Hamdan et al. [16] who reported development of resistance in larvae of $C$. quinquefasciatus against malathion in Malaysia. Kumar et al. [17] also reported the malathion resistance in $C$. quinquefasciatus from India. Difference among our findings and those, who found resistance in C. quinquefasciatus against malathion, might be due to insecticide usage profile.

Resistance development is a slow process which takes several years and successive generations to set up. It also depends upon the dosage and frequency of insecticide applied [18]. According to the information collected, University of Sargodha is not sprayed with insecticides regularly. However, the use of insecticides in Laboratory for research purpose is common but this usage is not sufficient to develop resistance in insects. Along with insecticide usage profile, there are many other co-factors for development of insecticide resistance, such as temperature, humidity [19] and rainfall [20].

Biochemical methods were used to detect the possible resistance mechanism in insects. Our results from biochemical estimation of enzymes showed that the activities of non-specific esterases, GSTs and monooxygenases among treated and control groups are not different statistically. Our result of biochemical estimation is correlated with bioassay. Malathion caused high mortality in mosquitoes in the study area and insect's enzymatic detoxification pathways have also not been activated. So, we concluded from the present study that malathion is still effective in area for control of mosquito population.

\section{REFERENCES}

[1] World Health Organisation (2011) Lymphatic filariasis. http://www.who.int/mediacentre/factsheets/fs102/en

[2] Abdel-Hameed, A.A., Dura, W.T. and Alkhalife, I.S. (2004) An inguinal mass with local vascular lesions induced by a lymphatic filaria. Saudi Medical Journal, 25, 1106-1108.

[3] McCarroll, L. and Hemingway, J. (2002) Can insecticide resistance status affects parasite transmission in mosquitoes? Insect Biochemistry and Molecular Biology, 32,
1345-1351.

http://dx.doi.org/10.1016/S0965-1748(02)00097-8

[4] Chareonviriyaphap, T., Sungvornyothin, S., Ratanatham, S.S. and Prabaripai, A. (2001) Insecticides induced behavioural responses of Anopheles minimus, a malarial vector in Thailand. Journal of American Mosquito Control Association, 17, 13-22.

[5] Lee, H.L. (2005) Vector of filariasis in Malaysia-A review. In: Kimura, E., Rim, H.J., Dejian, S. and Weerasooriya, M.V., Eds., Asian Parasitology Vol. 3 Filariasis in Asia and Western Pacific Islands. FAP Journal Ltd., Japan.

[6] Wondji, C.S., Priyanka De Silva, W.A., Hemingway, J., Ranson, H. and Parakrama Karunaratne, S.H. (2008) Characterization of knockdown resistance in DDT- and pyrethroid-resistant Culex quinquefasciatus populations from Sri Lanka. Tropical Medicines and International Health, 13, 548-555.

http://dx.doi.org/10.1111/j.1365-3156.2008.02033.x

[7] Hemingway, J., Hawkes, N.J., McCarroll, L. and Ranson, H. (2004) The molecular basis of insecticide resistance in mosquitoes. Insect Biochemistry and Molecular Biology, 34, 653-665.

http://dx.doi.org/10.1016/j.ibmb.2004.03.018

[8] Hemingway, J. and Ranson, H. (2000) Insecticide resistance in insect vectors of human disease. Annual Review of Entomology, 45, 371-391. http://dx.doi.org/10.1146/annurev.ento.45.1.371

[9] Enayati, A.A., Ranson, H. and Hemingway, J. (2005) Insect glutathione transferases and insecticide resistance. Insect Molecular Biology, 14, 3-8. http://dx.doi.org/10.1111/j.1365-2583.2004.00529.x

[10] Li, X., Schuler, M.A. and Berenbanm, R. (2007) Molecular mechanism of metabolic resistance to synthetic and natural xenobioatics. Annual Review of Entomology, 52, 231-253. http://dx.doi.org/10.1146/annurev.ento.51.110104.151104

[11] Baker, J.E., Fabrick, J.A. and Zhu, K.Y. (1998) Characterization of esterases in malathion resistant and susceptible strains of a pteromalid parasitoid, Anisopteromalus calandra. Insect Biochemistry and Molecular Biology, 28, 1039-1050.

http://dx.doi.org/10.1016/S0965-1748(98)00095-2

[12] Habig, W.H., Pabst, M.J. and Jakoby, W.B. (1974) Glutathione S-transferase, the first enzymatic step in mercapturic acid formation. Journal of Biological Chemistry, 249, 7130-7139.

[13] Vulule, J.M., Beach, R.F., Atieli, F.K., McAllister, J.C., Brogdon, W.G., Roberts, J.M., Mwangi, R.W. and Hawley, W.A. (1999) Elevated oxidase and esterases levels associated with permethrin tolerance in Anopheles gambie from Kenyan villages using permethrin impregnated nets. Medical and Veterinary Entomology, 13, 239-244. http://dx.doi.org/10.1046/j.1365-2915.1999.00177.x

[14] Roth, D., Henry, B., Mak, S., Fraser, M., Taylor, M., Li, M., Cooper, K., Furnell, A., Wong, Q., Morshed, M. and Members of the British Columbia West Nile Virus Surveillance Team (2010) West Nile virus range expansion into British Columbia. Emerging Infectious Diseases, 16, 
1251-1258. http://dx.doi.org/10.3201/eid1608.100483

[15] Duran, M. and Stevenson, H. R. (1983) Insecticide resistance in adult Culex quinquefasciatus mosquitoes from Olongapo City, Philippines. Southeast Asian Journal of Tropical Medicines and. Public Health, 14, 403-406.

[16] Hamdan, H., Sofian-Azirun, M., Ahmad, N.W. and Lee, L.H. (2005) Insecticide resistance development in Culex quinquefasciatus (Say), Aedes aegypti (L.) and Aedes albopictus (Skuse) larvae against malathion, permethrin and temephos. Tropical Biomedicines, 22, 45-52.

[17] Kumar, K., Sharma, A.K., Kumar, S., Patel, S., Sarkar, M. and Chauhan, L.S. (2011) Multiple insecticide resistance/ susceptibility status of Culex quinquefasciatus, principal vector of bancroftian filariasis from filarial endemic areas of northern India. Asian Pacific Journal of Tropical Medicine, 4, 426-429.

http://dx.doi.org/10.1016/S1995-7645(11)60119-3

[18] Radwan, E.M.M. (2012) Malathion resistance and acetylcholinesterase enzyme changes in field population of the peach fruit fly, Bactrocera zonata (Saunders). American Journal of Sciences, 8, 1042-1053.

[19] Bong, L.J. and Zairi, J. (2010) Temporal fluctuations of insecticides resistance in Musca domestica Linn (Diptera: Muscidae) in Malaysia. Tropical Biomedicine, 327, 317325.

[20] Bossard, R., Hinkle, N.C. and Rust, M.K. (1998) Review of insecticide resistance in cat flies (Siphonaptera: Puhcidae). Journal of Medical Entomology, 5, 415-422. 